\title{
Identifikasi Karakteristik Seni Lukis Flora dan Fauna Pengosekan Pada Seni Kerajinan Batu Padas di Desa Singapadu
}

\author{
Ni Putu Laras Purnamasari \\ Program Studi Pendidikan Seni Rupa, Fakultas Keguruan dan Ilmu Pendidikan \\ Universitas PGRI Mahadewa Indonesia \\ larassukanadi@gmail.com
}

\begin{abstract}
Seni lukis flora dan fauna Pengosekan pernah menjadi primadona dikalangan wisatawan diera tahun 1980-an. Lukisan jenis ini dijadikan sebagai elemen estetis interior hotel, restoran, ruang perkantoran, ruangan rumah sakit, hingga diekspor ke luar negeri sebagai produk suvenir. Bersamaan dengan masa kejayaan seni lukis flora dan fauna Pengosekan, representasi seni lukis tersebut ditemukan pada produk seni kerajinan batu padas di Desa Singapadu. Representasi yang terjadi ditinjau dari segi tema dan objek visualnya. Penelitian ini secara khusus mengulas mengenai proses terjadinya representasi tersebut, serta mengidentifikasi kesamaan bentuk visual yang melekat pada dua jenis kesenian tersebut. Penelitian ini merupakan penelitian kualitatif, dengan teori estetika dan teori representasi sebagai alat analisis. Hasil penelitian menunjukkan bahwa objek visual seni lukis flora dan fauna Pengosekan terepresentasi pada produk seni kerajinan batu padas di Desa Singapadu, yang terlihat dari segi tema serta karakter objek visualnya. Representasi yang terjadi dipengaruhi oleh adanya motivasi para perajin untuk menciptakan inovasi bentuk dari produk yang diciptakan, selain juga dipengaruhi oleh pasar yang berkembang saat itu.
\end{abstract}

Kata kunci: identifikasi; representasi; seni lukis Pengosekan; kerajinan batu padas; Singapadu.

\section{Identification Of Painting Arts In Padas Stone Crafts In Singapadu Village}

Pengosekan painting was once a favorite among tourists in the era of the 1980s. Pengosekan paintings are widely used as an aesthetic element of the interior of hotels, restaurants, office spaces, hospital rooms, and are exported abroad as souvenir products. Along with the heyday of Pengosekan painting, representations of this painting were found in several handicrafts. One of the handicraft arts that represents Pengosekan painting is the art of stone craft that has developed in Singapadu Village, Sukawati District, Gianyar Regency, Bali. There are similarities in terms of themes and the creation of solid stone craft objects with Pengosekan painting. This research specifically identifies the characteristics of the Pengosekan painting which is represented in the art of rock craft in Singapadu Village, as well as its influencing factors. This research is a qualitative research, using representation theory as analysis tools. The results showed that there was a representation of Pengosekan painting in the arts, which was seen in terms of the theme and character of the visual object. The representation that occurs is influenced by the artist's motivation to create innovation, as well as being influenced by the developing market at that time.

Keywords: identification, representation, Pengosekan painting, solid stone crafts, Singapadu. 


\section{PENDAHULUAN}

Seni lukis Pengosekan merupakan salah satu seni budaya Bali, yang pernah menjadi primadona oleh para wisatawan yang berkunjung ke Bali diera tahun 1980-an, serta menjadi identitas lokal daerah ubud dimasa itu. Objek lukisan yang sederhana menggambarkan binatang, bunga, dan dedaunan, berbentuk dekoratif, serta warna yang cenderung soft dengan penggunaan warna-warna pastel menjadi daya tarik dari lukisan Pengosekan, yang disebut sebagai lukisan flora dan fauna. Kesan yang lembut, teduh, dan nyaman sangat menarik wisatawan untuk melihat dan membeli lukisan tersebut sebagai cenderamata.

Banyak hal yang mempengaruhi perkembangan seni lukis Pengosekan, mulai dari pengaruh seni lukis Bali, Pita Maha, serta pariwisata. Pembangunan infrastruktur pariwisata Bali di era tahun 1980-an, membuat seni lukis Pengosekan kemudian dibutuhkan sebagai penunjang elemen estetis dari ruang dan arsitektur bangunan-bangunan tersebut.

Merebaknya produksi lukisan Pengosekan kemudian membuat banyak perajin tertarik untuk merepresentasikan objek lukisan Pengosekan ke dalam karya kerajinan mereka. Salah satu seni kerajinan yang merepresentasikan seni lukis Pengosekan adalah seni kerajinan batu padas yang berkembang di Desa Singapadu. Terdapat kesamaan dari segi tema serta betuk objek. Secara spesifik penelitian ini mengandung urgensi bagi pengembangan dan pelestarian seni budaya Bali, khususnya seni lukis Pengosekan terkait dengan masalah regenerasi.

\section{METODE PENELITIAN}

Penelitian mengenai "Identifikasi Seni Lukis Pengosekan Pada Seni Kerajinan Di Desa Singapadu", dirancang dengan menggunakan metode kualitatif. Sebagai penelitian kualitatif, analisis kajian juga menggunakan analisis kualitatif. Data yang berhasil dihimpun, baik data pustaka, visual, maupun lisan, dikelompokkan dan diklasifikasikan sesuai jenis, sifat, karakter data. Hasil pengolahan data tekstual yang telah dikonfirmasikan dengan data visual, data lapangan, dan hasil wawancara, dilanjutkan dengan pengujian dan interpretasi data, dilandasi sikap kritis dan selektif. Dengan demikian data yang diperoleh layak diangkat sebagai fakta dalam pembahasan. Hasil pengolahan data ini akan menjadi bahan penjelas mengenai ulasan permasalahan mengenai karakteristik dan implikasi seni lukis Pengosekan pada seni kerajinan batu padas di Desa Singapadu, dengan menggunakan teori estetika dan teori representasi sebagai pembedahnya.

Sumber Data yang digunakan dalam penelitian ini adalah sumber primer dan sumber sekunder. Sumber primer yaitu data yang langsung diperoleh dari hasil observasi, wawancara dan studi lapangan. Data ini diperoleh dari hasil wawancara terhadap beberapa informan dan observasi atau pengamatan secara langsung terhadap seni lukis Pengosekan dan seni kerajinan batu padas di Desa Singapadu. Sedangkan sumber sekunder adalan sumber yang diperoleh melalui berbagai dokumen, tulisan, laporan hasil penelitian serta literatur-literatur yang terkait dengan penelitian. Sumber sekunder ini dimanfaatkan sebagai penunjang sehingga dapat menyempurnakan sumber primer.

Metode Pengumpulan Data yang digunakan antaralain: a. Observasi lapangan yang digunakan untuk menggali data visual mengenai karakteristik seni lukis Pengosekan yang melekat pada seni kerajinan batu padas di Desa Singapadu. Observasi lapangan dilakukan dengan mengunjungi dua desa yaitu Desa Pengosekan dan Desa Singapadu. Data yang didapat dari kedua Desa tersebut kemudian dianalis untuk mendapatkan jawaban dari rumusan masalah penelitian. b. Metode wawancara yang digunakan untuk mendapatkan data berupa informasi-informasi secara lisan mengenai sejarah dan perkembangan seni lukis Pengosekan serta implikasinya pada seni kerajinan batu padas di Desa Singapadu dari tokoh pelukis, perajin, tokoh masyarakat, maupun budayawan sebagai pelengkap analisis yang dikembangkan.

\section{ANALISIS DAN INTEPRETASI DATA}

\section{Sejarah Perkembangan Seni Lukis Pengosekan}

Seni lukis Pengosekan adalah bagian dari seni lukis Ubud, yang memiliki karakter khas dan berbeda dengan seni lukis lain di wilayah Ubud. Perkembangan seni lukis Pengosekan terjadi setelah kedatangan beberapa pelukis Barat ke Ubud pada tahun 1930-an. Para pelukis tersebut antara lain Walter Spies, Rudolf Bonnet, Antonio Blanco, dan Arie Smit. Spies dan Bonnet datang atas permintaan Raja Ubud, Tjokorda Gede Agung Sukawati dan adiknya Tjokorda Raka Agung Sukawati dengan maksud ingin mengembangkan seni rupa di Ubud pada masa itu. Kedua pelukis itu kemudian membangun studio di daerah Ubud atas bantuan keluarga Puri Ubud. Spies dan Bonnet aktif melakukan pendekatan dengan para pelukis lokal di daerah Ubud dan sekitarnya, termasuk pelukis yang berada di Pengosekan. Usaha yang mereka lakukan adalah membimbing dan memotivasi para pelukis 
dalam pengembangan visual karya mereka, seperti berani dalam memilih tema penciptaan lukisan yang lebih luas.

Dalam mewadahi berbagai perkembangan dan aktivitas para pelukis, maka pada tanggal 29 Januari 1936 dibentuk organisasi Pita Maha (Picard, 2006: 114). Pendirian organisasi ini diprakarsai oleh Tjokorda Gde Agung Sukawati bersama dengan Walter Spies dan Rudolf Bonnet, didukung oleh beberapa pelukis asing, pelukis Bali, dan para pecinta seni. Tujuan didirikan organisasi Pita Maha adalah untuk memajukan serta mempertinggi mutu seni dari para pelukis Bali (I Wayan Widia dan Made Seraya, 1983/1984:21). Pita Maha memfasilitasi pelukis dalam hal distribusi bahan dan alat melukis, kegiatan pameran, serta berkontribusi dalam hal pemasaran hasil karya seni para pelukis yang bernaung dalam organisasi tersebut. Para pelukis mulai mempergunakan bahan-bahan melukis modern, seperti cat tempera dan cat air. Pengetahuan mengenai anatomi, proporsi, pencahayaan, dan persepektif, mulai diaplikasikan pada karya-karya lukisan mereka. Masa ini merupakan tonggak awal pertumbuhan aktivitas seni lukis di Pengosekan. Aktivitas melukis mulai beralih dari bersifat sakral menjadi lebih provan dan berorientasi pada materi. Nilai-nilai identitas seni lukis Pengosekan mulai dikonstruksikan, dan beberapa pelukis mulai mengukuhkan posisinya sebagai seniman individual (Patra, 2011:182).

Bersamaan dengan pecahnya Perang Dunia II, pada tahun 1942 Pita Maha dibubarkan. Belanda juga menyerah kepada Jepang pada tahun itu, sehingga jalannya pemerintahan diambil alih oleh Jepang. Pada masa penjajahan Jepang kegiatan berkesenian menjadi terabaikan, keamanan yang tidak stabil juga berdampak pada kurangnya kunjungan wisatawan ke Bali. Kegiatan berkesenian di Bali mulai berkembang kembali setelah kemerdekaan Indonesia. Rudolf Bonnet yang sempat menjadi tawanan Jepang di Makassar, kembali lagi ke Ubud tahun 1946, dan kemudian mendirikan perkumpulan Golongan Pelukis Ubud pada tahun 1956 (Agus Dermawan T. dan Jean Couteau, 2009:11). Dalam organisasi tersebut Bonnet kembali mengadakan kegiatan pendidikan melukis bagi para pelukis muda di daerah Ubud dan sekitarnya, termasuk Pengosekan. Sebagai tenaga pengajar diambil dari pelukis-pelukis lokal yang memiliki kemampuan yang baik dalam melukis. Dari Pengosekan terpilih I Gusti Ketut Kobot untuk mengajar melukis di desa Peliatan dan Pengosekan dengan anak didik sekitar 14 orang (Fajar Arcana dalam Enin Supriyanto dan JB. Kristanto, 2004:207).
Perubahan seni lukis di daerah Ubud semakin nampak setelah meninggalnya Rudolf Bonnet pada tahun 1978. Pada masa ini lahirlah era seni lukis pasca Bonnet yaitu Pita Prada. Aliran baru ini berusaha untuk menyingkirkan bayang-bayang Pita Maha dengan cara mencari identitas personal dengan berguru kepada situasi dunia modern yang dipenuhi teknologi informasi (Agus Dermawan T., 2009). Para pelukis mulai mencari "guru" lain yang dapat dijadikan panutan. I Gusti Ketut Kobot sebagai pelukis senior di Pengosekan terus memotivasi para pelukis muda, agar terus berkarya dan berinovasi. Sanggar-sanggar seni lukis tumbuh dibeberapa desa sekitar Ubud, yang dipelopori oleh pelukis-pelukis berpengaruh pada generasi 80-an, seperti I Nyoman Meja dari Banjar Taman, I Ketut Sana dari Desa Keliki, dua bersaudara I Dewa Putu Mokoh dan I Dewa Nyoman Batuan dari Desa Pengosekan.

Perkembangan seni lukis Pengosekan mulai terjadi setelah para pelukis mendapat kunjungan dan berinteraksi dengan para konsumen yang mengunjungi sanggar seni mereka. Konsumen tersebut tidak lain adalah para wisatawan domestik ataupun luar negeri yang berkunjung ke Pengosekan. Mereka banyak memberikan ide-ide kreatif dalam penciptaan karya seni lukis Pengosekan, beberapa diantaranya juga memberikan referensi gambar melalui buku ataupun majalah. Hal ini semakin membuka wawasan pelukis terkait pengolahan tema, bentuk, dan pewarnaan lukisan. Pengembangan ide kemudian dilakukan oleh para pelukis melalui eksperimen-eksperimen, hingga kemudian muncul inovasi dari seni lukis Pengosekan yang terlihat dari lukisan flora dan fauna. Lukisan bertema mitologi dan kehidupan sehari-hari yang telah ada sebelumnya, tetap berkembang dengan para pelukisnya yang telah mapan dengan tema penciptaan mereka.

Sejak awal tahun 1980-an lahir inovasi karya seni lukis Pengosekan bertema flora dan fauna. Desa Pengosekan mulai dikenal identitasnya melalui lukisan tersebut. Lukisan flora dan fauna lahir dari kreativitas pelukis, hasil dari eksperimen dan inovasi yang dilakukan terhadap karya seni lukis Pengosekan yang telah ada sebelumnya, serta merupakan pengembangan dari ide-ide yang diberikan oleh para kosumen yang tidak lain adalah para wisatawan yang berkunjung ke Pengosekan. Penciptaan lukisan flora dan fauna di Pengosekan dipelopori oleh I Dewa Nyoman Batuan. Beliau merupakan ketua dari sanggar seni yang bernama Community of artis Pengosekan. Kedekatan beliau dengan tokoh-tokoh budayawan di Bali, para relasi bisnis di bidang seni lukis, serta para investor 
properti yang menangani pembangunan hotel, restauran ataupun hunian pada masa itu, telah membuka akses bagi perkembangan seni lukis Pengosekan, khususnya lukisan flora dan fauna. Seni lukis flora dan fauna banyak diminati oleh konsumen, tidak hanya sebagai komoditi personal namun juga sebagai elemen estetis dari ruangan hotel, perkantoran, bahkan rumah sakit yang marak di bangun pada era tahun 1980-an. Pada dasarnya komersialisasi mampu mendorong motivasi ekonomi para pelukis untuk memproduksi produkproduk kreatif dalam memenuhi kebutuhan pariwisata (Mudana, 2017:71), dan hal ini lah yang terjadi pada kehidupan kesenian para pelukis di Pengosekan.

Dalam perkembangannya sanggar seni Community of Artist Pengosekan di bawah naungan Dewa Batuan, banyak melahirkan para pelukis muda yang menguatkan identitasnya sebagai pelukis flora dan fauna. Para pelukis tersebut yang paling menonjol diantaranya adalah I Dewa Made Kawan, I Dewa Putu Anom, I Gusti Putu Sana, I Dewa Putu Sena, dan I Dewa Nyoman Laba. Beberapa diantaranya kemudian membuat kelompok sendiri, hingga akhirnya mulai banyak sanggar atau kelompok seni lukis bermunculan di Pengosekan, seperti Communal of Artist di bawah bimbingan Dewa Putu Anom, dan Sana Grup dibawah naungan I Gusti Putu Sana. Dalam kelompok tersebut mereka mengajak sanak saudara serta kerabatnya untuk belajar melukis atau mengerjakan pesanan lukisan flora dan fauna yang booming di kisaran tahun 1980an hingga 1990-an.

\section{Karakteristik Seni Lukis Pengosekan}

Seni lukis bertema flora dan fauna sangat identik dengan desa Pengosekan, akan tetapi ada beberapa desa lain di Ubud yang juga menekuni lukisan dengan tema serupa, yaitu Desa Petulu, Kutuh, dan Sayan, akan tetapi karakter lukisan flora dan fauna yang hadir dari desa tersebut berbeda dengan lukisan yang ada di Pengosekan. Pada umumnya lukisan dari beberapa desa tersebut menggambarkan pemandangan alam dengan pohon-pohon rindang, tanaman bunga, bebukitan, gunung, sawah, sungai, dengan objek binatang seputar burung.

Seni lukis flora dan fauna Pengosekan menjadi sangat digemari karena memiliki ciri khas dan keunikan tersendiri. Karakter lukisan tidak hanya menampilkan keindahan, akan tetapi juga suasana kenyamanan, keteduhan, dan natural. Lukisan flora dan fauna Pengosekan tidak melukiskan landscape alam, yang berisi gunung, awan, ataupun sungai, akan tetapi pengambaran objek lebih bersifat potrait atau representasi artistik dari objek yang dilukiskan.
Secara keseluruhan objek yang ditampilkan cenderung dekoratif dengan deformasi dan stilisasi dibeberapa bagian, akan tetapi tidak meninggalkan bentuk asli dari objek. Para pelukis tetap memperhatikan detail, sehingga sangat terlihat natural. Lukisan terlihat sederhana dengan penggambaran beberapa objek saja, berbeda dengan lukisan Ubud lainnya yang cenderung menampilkan kerumitan dan mengisi penuh bidang gambar dengan objek lukisan. Hal ini lah yang membuat orang tidak mudah jenuh menikmati lukisan Pengosekan.

Hal yang paling menonjol dari karakter khas lukisan flora dan fauna Pengosekan adalah pemakaian warna-warna monokromatik, sehingga warna terkesan soft (lembut). Kesan monokrom pada lukisan Pengosekan dipengaruhi oleh teknik Nguap (memberikan sapuan warna transparan pada kanvas, seperti warna hijau, biru, atau coklat), sebelum atau sesudah dilakukan proses Ngabur (membuat gradasi warna hitam). Proses Nguap hanya dilakukan oleh pelukis di Pengosekan. Harmonisasi bentuk dan warna dari lukisan flora dan fauna Pengosekan membuat lukisan ini sangat mudah diaplikasikan sebagai elemen estetis ruangan. Lukisan Pengosekan dipilih karena dari segi estetika dapat dinikmati oleh berbagai kalangan masyarakat, dapat menyatu dengan suasana ruangan, tersedia dalam berbagai ukuran, dan terjangkau dari segi harga. Pada masa kejayaannya jenis lukisan ini sangat digemari, bahkan terjual hingga ke berbagai pelosok dunia.

\section{Representasi Seni Lukis pengosekan Pada Seni Kerajinan Batu Padas}

Menurut Struat Hall (1997), representasi merupakan salah satu praktek penting yang memproduksi kebudayaan. Ada dua proses representasi, yaitu 1) representasi mental, yang bersifat abstrak (konseptual) karena berada dalam benak individu maupun masyarakat, dan 2) representasi bahasa, yang merupakan penerjemah dari representasi abstrak. Sebagai penerjemah dari representasi abstrak, representasi bahasa berfungsi untuk menghubungkan konsep dan ide-ide tentang sesuatu dengan tanda dan simbol-simbol tertentu.

Secara filosofis, representasi dapat dibedakan sebagai aktivitas berfikir dan representasi sebagai produk dari kegiatan berfikir. Dengan kata lain, representasi menunjuk pada proses dan produk dari pemaknaan suatu tanda. Kegiatan berfikir berupa proses adalah sesuatu yang bersifat abstrak, sedangkan implementasi dari kegiatan yang abstrak itu menjadi suatu produk yang berbentuk konkret. 
Dari produk yang konkret inilah akan muncul pemaknaan (Kutha Ratna, 2008:123).

Terkait dengan hal diatas, tanda representasi seni lukis Pengosekan pada seni kerajinan batu padas dapat ditinjau dari segi tema, objek, gaya, komposisi, garis, dan volume. Merebaknya produksi lukisan flora dan fauna Pengosekan disertai dengan meningkatnya kehidupan ekonomi masyarakatnya, secara tidak langsung memberikan motivasi kepada seniman lain untuk mengembangkan karya mereka. Bersamaan dengan masa kejayaan seni lukis flora dan fauna Pengosekan, representasi seni lukis tersebut ditemukan pada beberapa barang seni kerajinan. Beberapa barang kerajinan tersebut antara lain, seni kerajinan batu padas di daerah Singapadu dan Silakarang, seni kerajian kayu seperti pembatas ruangan, pigura kaca, dan ukiran di Desa Singakerta, kerajinan batik Bali yang berkembang di Desa Sayan dan Kedewatan, serta seni kerajinan suvenir yang ada di daerah Tegalalang. Visualisasi lukisan flora dan fauna Pengosekan terepresentasikan pada barang-barang seni kerajinan tersebut. Pada perkembangannya seni kerajinan batu padas, ukir kayu, dan batik Bali mengalami kejayaan dimasa yang sama yaitu kisaran tahun 1980-an. Hal ini mengindikasikan bahwa seni lukis Pengosekan berkontribusi cukup besar dalam perkembangan seni kerajinan tersebut di atas. Tingginya minat wisatawan terhadap lukisan flora dan fauna Pengosekan, secara tidak langsung akan memotivasi seniman lainnya untuk merepresentasikan lukisan tersebut ke dalam seni kerajinan mereka.

Maraknya produksi lukisan flora dan fauna di Pengosekan dimasa itu, membuat lukisan tersebut akhirnya bersifat mass production. Banyak pelukis dari desa lain yang kemudian mencoba peruntungan melukiskan objek yang sama, namun mereka tidak menguasai pakem teknik melukis Pengosekan sehingga lukisan yang dihasilkan berbeda dari segi kualitas. Disisi lain para pelukis Pengosekan tetap konsisten dengan teknik pengerjaan yang sama. Akibatnya terjadi persaingan harga, hingga pertaruhan kualitas serta image dari lukisan flora dan fauna Pengosekan. Hal ini secara tidak langsung akan melemahkan serta menghancurkan identitas dari karya lukisan tersebut. Disisi lain representasi lukisan flora dan fauna Pengosekan pada seni kerajinan, semakin banyak memberikan alternatif pilihan produk kepada konsumen. Seni lukis flora dan fauna Pengosekan terrepresentasi menjadi bentuk yang baru pada medium yang berbeda. Hal ini semakin menciptakan persaingan harga, kualitas, dan konsumen.
Pada dasarnya representasi seni lukis Pengosekan merupakan dinamika yang terjadi pada perkembangan seni lukis tersebut, yang mengalir tanpa hambatan dan diterima oleh para pelukis maupun masyarakatnya. Mereka terbuka dan mengapresiasi segala perkembangan yang terjadi secara positif. Dengan adanya representasi pada seni lukis Pengosekan, secara tidak langsung juga memberikan konstribusi dalam mempertahankan eksistensi dari seni lukis tersebut. Selain juga memberi dampak positif bagi kehidupan sosial ekonomi masyarakatnya. Terjadinya representasi seni lukis Pengosekan pada karya-karya seni kerajinan sangat jelas menunjukkan adanya implikasi pada dua kesenian tersebut. Implikasi yang terjadi tidak hanya dari sisi penciptaan visual karya, akan tetapi juga pada sisi ekonomi, sosial dan budaya para perajin dan masyarakat disekitarnya. Kejayaan seni lukis Pengosekan menimbulkan motivasi kerja bagi para perajin untuk mengembangkan karya seni mereka. Saat ini banyak bisnis properti, hotel, villa, atau restoran yang memanfaatkan seni kerajinan sebagai elemen estetis interior ataupun eksterior ruangan. Disisi lain keberadaan seni lukis Pengosekan justru sedang mengalami kemunduran, hal ini dipengaruhi oleh faktor pemasaran atau promosi yang kurang maksimal, serta masalah regenerasi yang terputus. Representasi seni lukis pengosekan pada seni kerajinan merupakan hal yang positif, jika dipandang dari segi eksistensi seni lukis itu sendiri. Seni lukis Pengosekan tetap hidup meskipun dalam media yang berbeda. Dari segi perwujudan karya tentu tidak sama, namun adanya representasi visual tersebut tetap dapat diidentifikasi dari segi tema, objek, gaya, komposisi, garis, dan volume. Adapun uraiannya adalah sebagai berikut:

\section{Tema}

Sampai saat ini kerajinan batu putih di desa Singapadu salah satu tema yang dikerjakan adalah tentang kehidupan flora dan fauna, tema tema ini banyak diterapkan pada produk relief yang langsung menempel dinding baik pada rumah tiggal pribadi, vila, bahkan pada hotel hotel berbintang di bali. Kerajinan batu putih ini oleh perajinnya cendung dikerjakan sesuai dengan flora dan fauna yang dipesan oleh pemiliknya dan dikerjakan dengan alat serta teknik ukir khas Bali. Tema tema flora dan fauna juga diterapkan pada produk fungsional lainnya antara lain lampu taman dengan berbagai bentuk dan ukuran, produk ini banyak ditempatkan sebagai elemen estetis dan media penerangan di taman-taman kota di daerah Bali. Lampu taman dengan tema flora dan fauna juga banyak menghiasi area taman taman dalam vila atau resort dan hotelhotel bersekala besar di Bali. Lampu taman ini 
biasanya dikerjakan dengan kotruksi teknik susun, dengan bentuk segi empat maupun bulat dengan ronggga didalamnya untuk tempat menyimpan lampu, adapun teknik pengerjaan motif flora dan faunanya dilakukan juga dengan alat dan teknik khas bali terawangan( teknik ukir sampai membentuk lobang), maka lelalui terawangan atau lobang lobang pada motif itulah cahaya lampu didalamnya akan keluar, sehingga lampu taman saat dinyalakan dimalam hari motif dengan tema flora dan fauna akan kelihatan sangat artistic. Tema tema flora dan fauna kerap kali juga menghiasi berbagai bentuk pot untuk tanaman hias dengan betuk dan ukuran bervariasi, motif diterapkan pada bagian bidang luar pot dengan komposisi melingkar memenuhi bidang da nada kalanya juga begaya bergaya minimalis.

\section{Styl atau gaya}

Kerajinan batu putih dengan tema flora dan fauna sampai saat ini masih diminati oleh masyarakat Bali, sehingga berdampak positif terhadap dinamika kehidupan pada masyarakat perajin. Secara visual gaya seni kerajinan batu putih yang dikerjakan dan yang telah dihsilkan oleh perajin ada kesamaan dengan seni lukis flora dan faouna Pengosekan hal ini dapat dicermati dari cara mengatur komposisi, unsur objek yang disajikan dalam satu tema, kekuatan garis, serta pencapaian volume, namun demikian seni ukir akan tetap berbeda hasil akhirnya dengan capaian seni lukis.

Dalam pengaturan komposisi, penyusunan penempatan objek yang satu dengan yang lain dalam satu bidang tema garapan, para perajin batu putih juga mengadopsi pengaturan komposisi yang dilakukan oleh pelukis flora fauna di desa Pengosekan. Obyek disusun sedemikian rupa memenuhi ruang dengan berbagai bentuk objek flora dengan ekplorasi unsur daun, batang, buah, dan bentuk bunga, adakalanya unsur unsur tersebut disusun saling bertupang tindih sehingga obyek kelihatannya sangat padat, sedangkan objek fauna dijadikan sebagai pusat perhatian.

Teknik persepektif yang pakai oleh perajin batu putih dalam menyusun objek dan mengatur ruang juga mengunakan persepektif atas bawah, dimana obyek yang paling dekat akan ditempatkan di bagian bawah sedangkan obyek yang semakin jauh akan disusun semakin ke atas.

\section{Garis}

Unsur garis objek flora dan fauna pada seni kerajinan batu padas di desa Singapadu, memiliki karakter yang tidak jauh berbeda dengan garis pada seni lukis flora dan fauna desa Pengosekan. Garis yang tercipta pada setiap objek terkesan tegas, spontan, dengan sentuhan rasa estetik oleh senimannya sehingga mengasilkan karakter bentuk dari objek flora dan fauna yang tersusun sedemikian rupa dalam karya kerajinan batu padas yang sangat bervariatif. Garis berperan penting dalam menciptakan karakter pada setiap objek.

\section{Volume}

Volume yang dimaksudkan disini adalah demensi pada setiap unsur bentuk yang tersusun secara estetik dalan sebuah karya seni kerajinan flora dan fauna batu putih, untuk pencapaian velumenya tentu dengan teknik yang berbeda dengan teknik pada seni lukis. Dalam seni lukis velume bisa dicapai dengan teknik gelap terang atsiran atau teknik selah, aburan dalam bahasa bali, aakan tetapi dalan seni kerajinan flora dan fauna batu putih bisa dicapai hanya dengan teknik ukiran serta di bantu dengan pencahayaaan sehingga velume pada setiap bentuk akan napak dengan jelas.sempura dan tidaknya velume dalam seni kerajinan flora dan fauna batu putih sangat ditentukan oleh pemampuan teknik mengukir, tinggi rendah, serta cekung cembungnya ukiran yang dikerjakan.

\section{SIMPULAN}

Seni lukis Pengosekan merupakan salah satu seni budaya Bali, yang pernah menjadi primadona oleh para wisatawan yang berkunjung ke Bali diera tahun 1980-an, serta menjadi identitas lokal daerah ubud dimasa itu. Objek lukisan yang sederhana menggambarkan binatang, bunga, dan dedaunan, berbentuk dekoratif, serta warna yang cenderung soft dengan penggunaan warna-warna pastel menjadi daya tarik dari lukisan Pengosekan, yang disebut sebagai lukisan flora dan fauna. Kesan yang lembut, teduh, dan nyaman sangat menarik wisatawan untuk melihat dan membeli lukisan tersebut sebagai cenderamata.

Merebaknya produksi lukisan Pengosekan kemudian membuat banyak perajin tertarik untuk merepresentasikan objek lukisan Pengosekan ke dalam karya kerajinan mereka. Beberapa barang kerajinan tersebut antara lain, seni kerajinan batu padas di daerah Singapadu dan Silakarang, seni kerajian kayu seperti pembatas ruangan, pigura kaca, dan ukiran di Desa Singakerta, kerajinan batik Bali yang berkembang di Desa Sayan dan Kedewatan, serta seni kerajinan suvenir yang ada di daerah Tegalalang. Visualisasi lukisan flora dan fauna Pengosekan terepresentasikan pada barangbarang seni kerajinan tersebut. Pada perkembangannya seni kerajinan batu padas, ukir kayu, dan batik Bali mengalami kejayaan dimasa yang sama yaitu kisaran tahun 19 berkontribus80- 
an. Hal ini mengindikasikan bahwa seni lukis Pengosekan berkontribusi cukup besar dalam perkembangan seni kerajinan tersebut di atas. Tingginya minat wisatawan terhadap lukisan flora dan fauna Pengosekan, secara tidak langsung akan memotivasi seniman lainnya untuk merepresentasikan lukisan tersebut ke dalam seni kerajinan mereka.

Representasi seni lukis pengosekan pada seni kerajinan merupakan dinamika yang terjadi pada perkembangan seni lukis tersebut. Praktik representasi secara tidak langsung juga merupakan hal yang sangat penting dan positif dalam menjaga eksistensi seni lukis itu sendiri, walaupun dalam visualisasinya sedikit berbeda karena disebabkan oleh beberapa faktor diantaranya, medianya tidak sama dengan media lukisan, demikian juga teknik pengerjaan kerajinan batu padas sangat berbeda, hal ini dapat dicermati dari aspek, yaitu tema, media, alat yang digunakan, serta teknik pengerjaannya, namun demikian representasi seni lukis Flora dan fauna Pengosekan dapat diidentifikasikan dari berbagai unsur atara lain: Tema, stail atau gaya, komposisi, unsur obyeknya ( flora dan Fauna), garis dan volume.

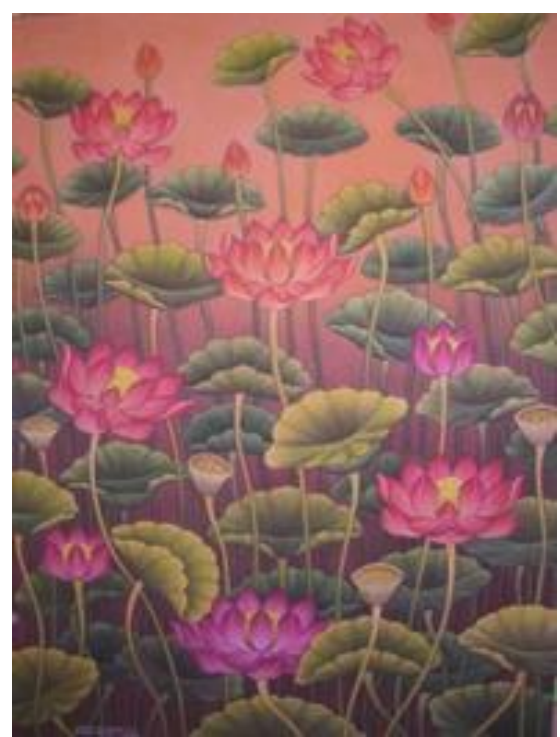

Gambar 1. Lukisan Pengosekan karya I Dewa Ketut Narayana, Lisah dan Nuri, akrilik di kanvas, 80x60 cm, 2002 (kiri), lukisan Pengosekan karya I Dewa Made Bawa, Lotus, tinta dan akrilik di kanvas, 90x60 cm, 1997 (kanan)

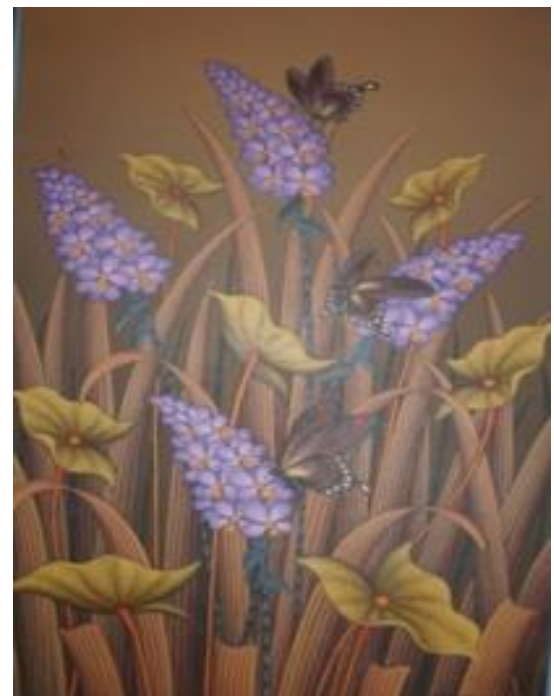

Gambar 2. Lukisan Pengosekan karya I Gusti Kompyang Wardhana, Kupu-kupu, 90x65 cm, 2010. 

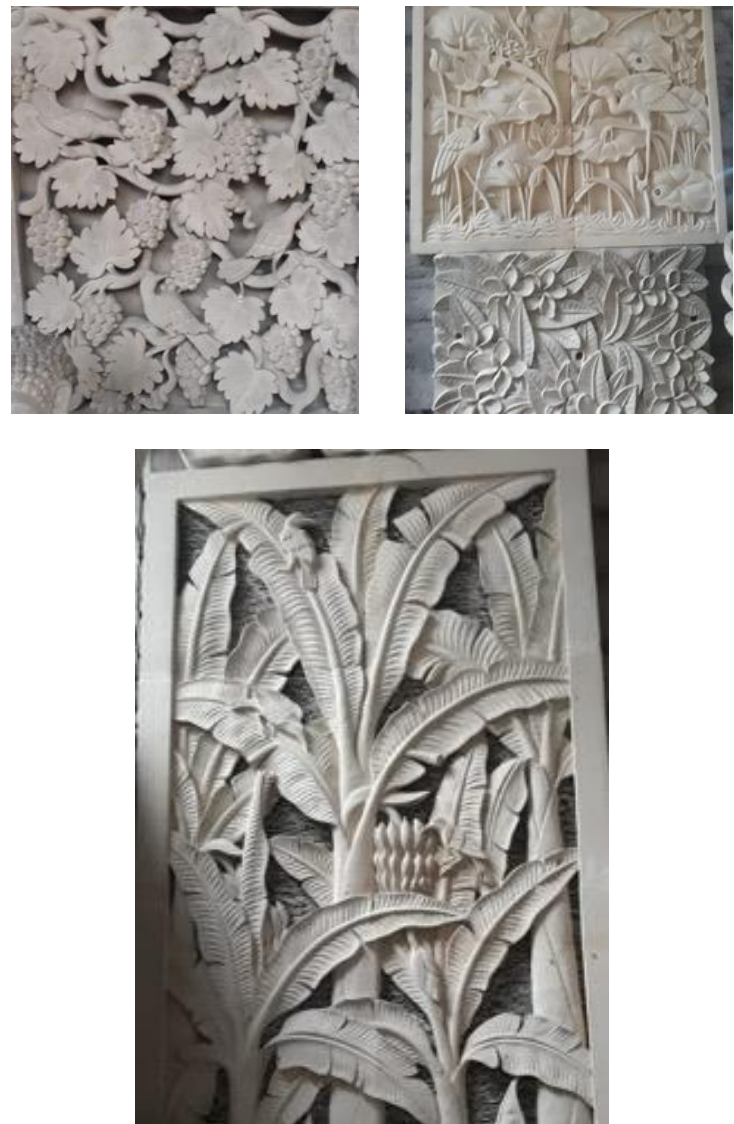

Gambar 3. Seni kerajinan batu padas bertema flora dan fauna di Desa Singapadu.

\section{DAFTAR RUJUKAN}

Arcana, Putu Fajar. 2004. "Lukisan Bali Pengabdian dan Penghambaan" dalam Enin Supriyanto dan JB Kristanto, ed., Perjalanan Seni Lukis Indonesia Koleksi Bentara Budaya. Jakarta: Kepustakaan Populer Gramedia.

Berata, I Made. 2009. "Dinamika Perkembangan Seni Ukir Batu Padas Di Silakarang, Gianyar, Bali”. Prosiding Seminar Nasional Seni Kriya, Yogyakarta: Lembaga Pengkajian dan Penerbitan Seni Kriya ISI Yogyakarta (LPPSK).

Dermawan T., Agus. 2007. Bali Bravo: Lexicon of 200 Years Balinese traditional painters. Jakarta: Panitia Bali Bangkit.

Hill, Christoper. 2006. Survival and Change: Three Generation of Balinese Painters. The Australian National University: Pandanus Books.

Mudana, I. W., \& Ribek, P. K. (2017). Komodifikasi Seni Lukis Wayang Kamasan Sebagai Produk Industri Kreatif Penunjang Pariwisata. Mudra
Jurnal Seni $\quad$ Budaya,
https://doi.org/10.31091/mudra.v32i1.83

Muka, I Ketut, 2016, "Inovasi Produk Kerajinan Batu Padas Tradisional Era Globalisasi Di Desa Singapadu Kaler Gianyar”, Disertasi.

Muka, I. K., \& Rai Sunarini, N. M. (2018). Forms And Functions Of Sandstone Handicrafts In Singapadu Kaler Village In The Global Era. Mudra Jurnal Seni Budaya, 33(3), 360-366. https://doi.org/10.31091/mudra.v33i3.500

Patra, I Wayan Seriyoga. 2011. "Perkembangan Seni Rupa Pita Maha Dalam Konteks Konstruksi Kebudayaan Bali". Mudra Jurnal Seni dan Budaya, Volume 26, Nomor 2, Juli 2011. P 181-192.

Purnamasari, Ni Putu Laras. 2017. "Seni Lukis Pengosekan: Kontinuitas dan Perubahan", Jurnal Widyadari, No. 22 tahun XVIII Oktober 2017.

Suardana, I.W. 2010. "Fungsi Seni Kerajinan Ukir Batu Padas Sukawati II" Institutional Repository ISI Denpasar. Artikel bulan Juli 2010. 7. pp. 1-5. 
Sukarini, N. W., Beratha, N. L. S., \& Rajeg, I. M. (2019). Industrialisasi Seni Kriya Di Desa Mas, Gianyar. Mudra Jurnal Seni Budaya, 34(1), 45-52. https://doi.org/10.31091/mudra.v34i1.634

Vickers, Adrian. 2012. Balinese Art Paintings and Drawings of Bali 1800-2010. Singapore: Tuttle Publishing.

Sudarta, G.M., 1995. Seni Lukis Tradisional Bali Gaya Ubud dan Batuan, Jakarta: Bentara Budaya.

Widia, I.W.,\& Seraya, I.M. 1983/1984. Mengenal Seorang Tokoh Idealis Pendiri Museum Puri Lukisan Ratna Wartha Ubud Tjokorda Gde Agung Sukawati. Denpasar: Proyek Pengembangan Permuseuman Bali Direktur Jenderal Kebudayaan Departemen Pendidikan dan Kebudayaan. 